but so have those of other types of electrophoresis, not to mention non-electrophoretic methods. Consequently to concentrate on one technique, as this chapter does, carries the danger of giving the erroneous impression that this technique has played a major part in advancing knowledge in some important fields. Some examples are the isolation and properties of human $\beta_{2}$ serum globulins, structural studies of immunoglobulins (it is admitted in this section that "analysis on Sephadex columns also proved fruitful" for this purpose !), human haemoglobin varieties and the study of plasmocytoma. Many of the detailed discussions of these and other subjects are scarcely relevant to a book of this nature and publications about them exist which cover all the analytical methods. This chapter docs show that agar-gel electrophoresis is a useful complementary analytical technique, however, and the full coverage of the literature will be of great value to those who may want to use it for their own particular problems.

Agar gel electrophoresis is probably not so widely used in Britain as it is in the author's own country and other Continental countries. It has been used with great success in some important fiolds, a good example being isoenzyme studies. In general this book, well printed and illustrated, provides excellent guidance on the methodology of agar gel electrophoresis and should encourage its wider use.

R. CONSDEN

\section{VANISHING PEOPLE}

\section{Documents Anatoliens sur les Langues et les Traditions} du Caucase

Par Georges Dumézil. 3: Nouvelles Études Oubykh. (Université de Paris. Travaux et Mémoires de l'Institut d'Ethnologie, 71.) Pp. 269+6 planches. (Paris: Institut d'Ethnologie, 1965.) 60 francs.

THE Ubykh are a small but important branch of the Caucasian family of peoples, closely related to the Circassians and the Kabardians. Since Greek and Roman times, they are reported as inhabiting a stretch of the Black Sea coastline between Abkhazia and the Crimea, not far from the modern Sochi. In 1864, the Russian conquest of the Caucasus resulted in the total dispersion of the Ubykh people, one segment being deported to the province of Kostroma, the other preferring to emigrate en bloc to the Ottoman Empire, to join forces with their Muslim co-religionists. In both cases, linguistic and cultural assimilation proceeded apace. To-day, Ubykh is spoken and understood only by a handful of old men, and these are rapidly dying out.

The interest presented by the Ubykh and their language was appreciated by scholars over the past century; the Russian Baron Uslar, the German Dirr and the Hungarian Mészáros all produced valuable pioneer studies. Much remained to be done, however, towards recording the vocabulary and phonology of this unique language before its final disappearance. Prof. Georges Dumézil, of the Collège de France, whose publications in the Caucasian field cover more than 30 years, has for several years been making annual trips to the remaining Ubykh villages in Turkey to preserve and interpret the vestiges of Ubykh folklore and oral tradition. This latest volume in his series of Ubykh publications commemorates the centenary of the annihilation of the Ubykh nation by Tsarist troops. Opening with a historical narrative of the last years of the independent Ubykh people, and biographical notes on Ubykhs whom tho author has known, the book continues with nearly 150 pages of fresh Ubykh textstraditional stories, anecdotes and personal reminisconces, of Caucasian and Turkish provenance-given with French and Kabardian translation. There is also an analysis of Hans Vogt's Ubykh dictionary, published at Oslo in 1963, as well as miscellaneous notes on Ubykh grammar and personalia. With six plates depicting the life of the survivors of this dying warrior nation, the book is a worth while addition to all libraries of ethnography anthropology and linguistics.

David M. LANG

\section{The Principal Diseases of Lower Vertebrates}

By H. Reichenbach-Klinke and E. Elkan. Pp. xii +600 . (London: Academic Pross, Inc. (London), Ltd.; New York: Academic Press, Inc., 1965.) I26s.

THIs book fills a gap in the literature and brings together a vast amount of information on the pathology, bacteriology, zoology and parasitology of fishes, amphibians and reptiles. It is not a "popular" book but can be recommended to students.

Although the cover citation states that the book "is designed to help owners of such animals to maintain healthy stock, to afford some explanation of the losses they invariably suffer and to suggest tho means of avoiding their occurrence", I consider it to be much too advanced for the ordinary owner. It will, however, find a place in laboratories which conduct post-mortem examinations and carry out investigations into losses of animals in these three groups.

Tho problem of diseases in these animals is immense, and this book emphasizes the difficulties of diagnosis, particularly in fishes. The present outbreak of disease among salmon in the Republic of Ircland is a case in point. Despite weeks of careful investigation, no clear pronouncement on the cause of the trouble has yet been made. To a pathologist this book emphasizes the unity of pathology in all species. The diseases and parasites of domestic animals have their counterparts in the lower animals and the means of investigation are not dissimilar.

Part I deals with fishes. Methods of investigation, infectious diseases, non-infectious diseases, environmental factors, healing of wounds and regeneration are adequately covered. Chapter 6 is devoted to lampreys, and Chapter 7 deals with fish as carriers of human disease. In Chapter 8 is given a useful review of the main symptoms and localization of fish diseases. Chapter 9 deals with treatment but emphasizes the importance of hygiene. Treatment at the moment does not seem too promising and prevention is obviously to be aimed at. Part II deals with amphibia, and Part III with reptilia, on similar lines to those on fishes.

Altogether this book is most interesting and the authors are to be congratulated.

H. G. LAMONT

\section{Advances in Chemotherapy}

Vol. 2. Editod by Abraham Goldin, F. Hawking and Robert J. Schnitzer. Pp. $\mathrm{x}+330$. (New York: Aczdemic: Press, Inc.; London: Academic Press, Inc. (London), Ltd., 1965.) \$13.

LrkE its predecessor, this book devotes nearly half its space to the chemotherapy of cancer, but the emphasis is perhaps more derived from the volume of work than the rate of advanco in this field. What advances have been made in the recent past stem not from new drugs but from the more skilful clinical application of those drugs already available. This is described with a fascinating precision by Frei and Freireich in thoir account of the four-drug attack on leukaomia being conducted in the United States. Wallace Fox's chapter on "Tuberculosis" presents a most interesting comparison. He also describes a pattorn of combined theræpy with streptomycin, $p$-aminosalicylic acid and isoniazid, and even though the antitubercular drugs available can achieve cures---which are most rare in the loukanmiasthe author comments that " $100 \%$ success has only been 